\title{
Intersections in Law, Culture and the Humanities
}

Interseções entre o direito, a cultura e as humanidades

Intersections entre loi, culture et les sciences humaines

\section{Patrícia Branco and Valerio Nitrato Izzo}

\section{(2) OpenEdition}

\section{Journals}

Electronic version

URL: http://journals.openedition.org/rccs/6574

DOI: $10.4000 /$ rccs.6574

ISSN: 2182-7435

\section{Publisher}

Centro de Estudos Sociais da Universidade de Coimbra

\section{Printed version}

Date of publication: 1 May 2017

Number of pages: $45-72$

ISSN: 0254-1106

\section{Electronic reference}

Patrícia Branco and Valerio Nitrato Izzo, «Intersections in Law, Culture and the Humanities », Revista Crítica de Ciências Sociais [Online], 112 | 2017, Online since 15 May 2017, connection on 03 May 2019. URL : http://journals.openedition.org/rccs/6574; DOI : 10.4000/rccs.6574 


\section{PATRÍCIA BRANCO, VALERIO NITRATO IZZO}

\section{Intersections in Law, Culture and the Humanities*}

Ever more often, researchers and scholars endeavor to situate law in its social, political, historical and cultural contexts. At the same time, there is a need to invest law and the social sciences with new roles and resources. We thus propose to look for the many intersections of law, culture and the humanities by presenting four topical preoccupations: (1) interlegality in everyday life; (2) the synesthesia of law; (3) material socio-legal studies; and (4) interactive ecologies of knowledges and methodologies. This will constitute part one of the paper. Parts two and three will look at two particular and very recent interdisciplinary relationships: those between law and music and between law and food. We thus propose it would be appropriate to expose students, learners and practitioners of all kinds to the difference that an understanding of the links between law, culture and the humanities makes.

Keywords: culture; ecology of knowledge; food; humanities; law; music; socio-legal studies.

\section{Introduction}

Ever more often, researchers and scholars, in disciplines as varied as the sociology of law, legal anthropology or postcolonial studies of law, endeavor to situate law in its social, political, historical and cultural contexts. At the same time, there is a need to invest law and the social sciences with new roles and resources. This is why, a couple of decades ago, a stance that - using a range of interdisciplinary approaches to the study of the law and normativity - sought new sites where law happens and is experienced on a daily basis, emerged in law and the humanities. More recently, in what has been called the 'cultural turn' in legal studies, there emerged the imperative to analyze law as a cultural practice, as something that dynamically creates the (social,

\footnotetext{
* The authors wish to thank the valuable comments made by the two anonymous reviewers. This article is the product of a joint intellectual effort by the two authors, who concur on all reflections and conclusions expressed in the article. However, they would like to point out that individual sections should be attributed as follows: Patrícia Branco for sections 1 and 3; and Valerio Nitrato Izzo for sections 2 and 4.
} 
cultural and political) world as we experience and understand it (Coombe, 2001; Sarat and Simon, 2001; Carlson, 2013; Olson, 2017).

Nevertheless, research on the complex intersections between law, culture and the humanities continues to be a secondary aspect of socio-legal studies (Moran, 2012). According to Lopes (2010), we could learn a lot more about law and justice through the other languages used to speak of it (aesthetic, architectural, musical, literary, etc.) than through a supposed 'theoretical cleanliness'. Nevertheless, as Feenan (2009: 235) claims, inquiry into the relationship of the humanities to socio-legal studies still needs to gain a broader and common acceptance.

We have before us, therefore, a porosity and flexibility that is capable of accommodating different modes of knowledge interpenetration, creating interdisciplinary associations that were absent from previous discussions and analysis. In this paper we seek to explore these interdisciplinary relations, looking at/for different perspectives offered by the humanities and cultural studies of law. Such perspectives, usually absent from the (hegemonic) discourse on legal phenomena, question the legal, political and social fields by implying each other and by encouraging dialogues that may not always be easy but which are richer and reflect (legal, social or political) changes or the need for such changes.

We thus propose to look for the intersections or contact zones of law, culture and the humanities by offering four thematic approaches: (1) interlegality in everyday life; (2) the synesthesia of law; (3) material socio-legal studies; and (4) interactive ecologies of knowledges and methodologies. This will constitute part one of the paper. The choice of these four thematic preoccupations - which do not intend to be exhaustive but signal some of the directions where the field is going - came almost naturally, because they have emerged in the recent literature we have analyzed. At the same time, we wanted to avoid engaging with the main topics that have been surveyed, mainly those concerning identity, community, ideology, power, narrativity and visuality. Thus our aim is to offer an updated and complementary survey of more conventional socio-legal literature, a sort of road-map of what has been recently discussed concerning the multiple relationships between law, culture and the humanities.

While the law and humanities connection is, in many ways, a somewhat established, and even respected, kind of (socio)legal scholarship, some of its developments are not yet satisfactory. We still have a long way to go before the role of the humanities can be defended from the attacks of the efficientist, economics-driven culture that still permeates academia. In this respect, all organizations and institutions working in the field will be busy in the future. 
Some interrogations of further developments in the field must therefore be undertaken, albeit not in an exhaustive manner.

Parts two and three will look at two specific and quite recent intersections in the field. Part two will be devoted to examining some of the relations between law and music, while part three will examine possible connections between law and food. Why these topics? Firstly, both authors share a passion for music and enjoy eating (well). ${ }^{1}$ Secondly, their research interests eschew a purely legal-philosophical and/or socio-legal approach to law, engaging rather in interdisciplinary views and methodologies. So it seemed only natural to bring both areas together and look for ways in which those links could be established, in law and music and in law and food. Other possible connections or intersections are, of course, both possible and welcome. Finally, music and food relate in many ways to the thematic preoccupations that structure this article: they are both material and sensory, and they both form a considerable part of our everyday lives, interacting with our knowledges and pushing us further toward recognizing and understanding the multiple social contexts in which we live.

We will conclude by arguing that the possibilities that the vast field of law, culture and the humanities makes available to depict and expose the current state of affairs in the world are still so promising that it would be an intolerable waste of experience not to keep it moving toward this goal.

Before we proceed to the next sections, it is necessary to make a few conceptual clarifications.

While the humanities are or seem to be easier to define, the concepts of law and culture pose some challenges. All three are interrelated and sometimes juxtaposed, which means that their boundaries are by no means closed and stable, but are "complex, contested and historically located" (Merry, 1998: 575), mutually shaping each other through "dynamic, interactive and dialectical" relationships (Mezey, 2015:39). All this goes to show the difficulty of defining culture. In fact, culture has a very contested meaning and therefore needs to be understood in a broad sense, as the materialization of shared meaning encompassing beliefs, values, traditions, viewpoints or matters of affect, "a plurality of not necessarily harmoniously co-existing forms" (Cotterrell, 2008: 25).

As Mezey (2015: 39) asserts, law is at once a producer and an object of culture in its innumerable manifestations, which include the humanities. Cotterrell (2004) has outlined six points of investigation between law and

\footnotetext{
${ }^{1}$ Also, both authors come from countries - Portugal and Italy - where culture and normativity intersect and are involved in the arrangement of the social context concerning their respective gastronomies. Codfish or pasta, fado or canzone napoletana, seem to be the epitome of their identities when abroad, given the weight of the normativities assigned to each staple food or musical tradition.
} 
culture: (1) law's dependence on culture; (2) law's recognition of culture; (3) law's domination of culture; (4) law as an object of cultural competition; (5) law as a cultural projection [and here there is a juxtaposition with the humanities, as products of popular culture in their multifaceted experiences]; and (6) law's stewardship of culture, which is another way of saying culture's dependence on law. There is thus no single relationship between law and culture (Cotterrell, 2008).

As regards the law, we use the word in three different senses throughout the article: as official state law; as professional scholarship on official state law; and as the diversity of human normativity. This multiplicity of senses speaks for the diversity of experiences and uses of law in everyday life.

\section{Intersections}

As Knox and Davies (2013: 1-2) argue, law's intersections with disciplines from the humanities and social sciences had been established before the so-called 'cultural turn'. As the authors point out, legal anthropology, feminist studies, critical legal studies, history and other disciplines opened up the study of law by casting light upon its hidden operations of meaning, thus re-contextualizing law and its (visible and invisible) effects of regulation, exclusion and inclusion, concealment and empowerment.

Whereas at the inception of this field of study, law and humanities scholarship was mostly identified with law and literature (through various approaches, such as law in literature or law as literature) and as a "reaction specifically to law and economics", the canon has opened up in order to accommodate other modes of examination and contextualization. This calls into play a plurality of approaches that go beyond the textual to incorporate the visual, the symbolic, the iconographic, the material, the sonic, the spatial or the sensorial and/in/as the law, strengthening the imbrications between legal phenomena and narrativity, visuality, performance, materiality and affects ${ }^{2}$ (Olson, 2017; Sarat et al., 2010: 9; Philippopoulos-Mihalopoulos, 2013).

Nonetheless, the specific outline of a humanistic and cultural study of law is by no means clear (Sarat et al., 2010: 1). Coombe (2001) claims that no substantial body of work demonstrating methodological commitments or theoretical grounds has yet appeared, which makes it difficult to define the field of study or to offer an agenda of investigation in advance. However, this too clears the field of many constraints, as it renders the imbrications and hybridity much richer and more interesting, and adopts methods and

${ }^{2}$ Greta Olson's recent essay inquires whether law and literature has not already been supplanted by law and affect (Olson, 2016). 
approaches from other disciplines, revitalizing the study and understanding of law, especially at a time when we are confronted with pressing global/local geopolitical realities (Darian-Smith, 2013).

The development of a law, culture and humanities scholarship ${ }^{3}$ has been a difficult process, for it has been perceived at times as 'useless' and not offering a practical understanding of the law, or even as potentially damaging the law's claims to being considered a science (Sarat, Anderson and Frank, 2010). But as these authors point out, perhaps we need to expand our notion of what is useful and important in (socio)legal studies, grounding law in a model of value that is qualitative and not merely quantitative, and uncovering the operation of law in everyday life as well as the operation of everyday life in law (Olson, 2017; Sarat, Anderson and Frank, 2010).

To address these issues, we propose to explore what we have identified as the most recent and interesting thematic preoccupations in the humanistic and cultural scholarship of law and socio-legal studies.

\subsection{Interlegality in Everyday Life}

The title of this section encompasses a number of notions developed by Santos, Silbey and Ewick. Santos argues that interlegality is a dominant characteristic of our times, because our legal life is constituted by an intersection of different legal orders. We are thus faced with a world of legal hybridizations, a condition that is present not only at the structural level of the relationship between those different legal orders, but also at the level of legal behavior, experiences and representations of citizens and social groups (Santos, 1995). Ewick and Silbey (1998) claim that legality - which refers to the meanings, sources of authority, and cultural practices that are recognized as legal, irrespective of their institutional manifestations - is constituted through everyday negotiated transactions, involving "everyday people in everyday places" (Marusek, 2007: 252). In sum, a humanistic, socio-legal and cultural study of the law claims that normativity is plural, ${ }^{4}$ and these pluralities take place

\footnotetext{
3 The scholarship is manifest in a proliferation of articles, both in traditional venues and in dedicated journals; through the creation of specific academic associations (such as the Association for the Study of Law, Culture and the Humanities; The Law, Literature \& the Humanities Association of Australasia, or The Italian Society for Law and Literature); through blogs (e.g. Law \& Humanities Blog); through edited and single authored volumes; through undergraduate and postgraduate university courses; and through annual conferences and workshops.

${ }^{4}$ Accounting for interlegality - or legal pluralism, as other scholars, such as Sally Engle Merry, refer to it - provides alternative understandings and practices of law that not only show that the law, in its plurality, is pervasive in everyday life, but also lay bare the fragmentation, contradiction and inconsistency of that same law at the local/national/regional/global level and the constant interaction between the different legal orders and their mutual redefinition. Last accessed on 31.10.2016, at https://www.youtube.com/watch?v=A2j2FBr0wgw.
} 
in and shape every aspect of our daily lives, even if or when we are not aware of the fact. Thus, the law "permeates and is inseparable from everyday living and knowing", and it plays an important role in shaping (legal) consciousness (Coombe, 2001: 43). It penetrates and influences social practices, and makes "asymmetries of power seem, if not invisible, natural and benign" (Sarat and Simon, 2001: 19).

Therefore, the workings of the law are encountered not only in its authoritative spaces, such as the courthouse, "but also when it is consciously and unconsciously apprehended" (Coombe, 2001: 57). As Brigham (2009a) claims, law has moved away from the confines of professional knowledge and become part of the way we live. Characteristics of law that may not be evident when looked at through its traditional institutions can then emerge. We are thus able to recognize law in relationships, artefacts, images, buildings, songs or landscapes. Hence, seeing a homeless person tells us something about the power of property; likewise, the tears shed in Family Court are "law-related tears" (Brigham, 2009a: 386). (Inter)legality occurs when we park the car or leave our umbrella in a public place (Ewick and Silbey, 1998: 337), choose, buy and prepare our food (Meneses, 2016), in the ways we dress (Watt, 2013), when we go see a movie (Silbey, 2012), when odors enter our nostrils (Branco and Mohr, 2015), when songs are played in a concert hall or in football stadiums, and even in the courtroom (Grant, forthcoming; Parker, 2015b), and it is also found on the walls and façades of buildings (Philippopoulos-Mihalopoulos, 2013).

But seeing or feeling the law in ordinary life is difficult, and interpreting the quotidian cultural and social forms of interlegality is a complex task, given that legal meaning is found and recreated every day and everywhere (Sarat and Simon, 2001; Brigham, 2009a). It actually may seem as if this "lawscape" (Philippopoulos-Mihalopoulos, 2013), this interfolding of law with all the material and immaterial/sensory aspects of our daily lives, is a totalizing capsule from which one cannot escape, as if the eye/ear/mouth/nose/ /hand of the law is everywhere, controlling us and suppressing our agency. Nevertheless, in their many and plural social relationships, people too use and deploy meanings strategically to advance interests and goals, contesting and contradicting legality/illegality/a-legality, thus inviting adaptation and change in legal practices (Sarat and Simon, 2001). That is precisely the advantage of all the recent scholarship in this field: to unveil the intersections of governance, order, contestation and resistance that we inhabit and occupy on a daily basis and which are the cause of disputes over equality, legitimacy and justice (Marusek, 2007). 


\subsection{The Synesthesia of Law}

As Ewick and Silbey argue (1998: 15), in everyday life "we rarely sense the presence or the operation of the law". However, as Philippopoulos-Mihalopoulos (2013: 110) points out, all the senses are invoked in one's experience of the lawscape, and in the lawscape, every surface, smell, color, taste and sound is regulated by some form of law. Law is thus found not only in judicial decisions, legislation, or contracts, but also in the smell of trees burning in the Amazonian forest, in the flavor of the tomatoes or vegetables we eat, in the nursery rhymes and protest songs we hear (Parker, 2015a; Levin and Jamin, 2016), or in the urban landscapes we inhabit, where issues as diverse as housing, spatial segregation or street art have a direct legal component. In addition, legal conflicts often have an emotional dimension, but judicial proceedings, governed by strict rules and rituals, control and regulate the display of affect and emotion in the courtroom (Dahlberg, 2016).

A new brand of sensory-social-legal scholarship is, then, a work in progress. But a significant number of conferences/seminars, ${ }^{5}$ monographs and articles have recently been organized and published, that attest to the increasing importance of this field in terms of widening the canon with regard to the situatedness and concreteness of the law, but also its synesthesia; and this in turn has led to new ways of responding to current political, juridical and socio-cultural conflicts that, much like law, transcend and transgress social, cultural, institutional, geographical, material and sensory boundaries ${ }^{6}$ (Levin and Jamin, 2016).

Thus synesthesia, according to Marusek (2016: 1), is "the phenomenon in which sensual perceptions are joined together as a combined experience" (for example, the capacity to sense color). According to the author, an analysis of such sensual perceptions gives a greater and creative insight into the complexities of how law works through the body (hands, ears, eyes, nose, tongue) in the different (spatial, temporal, audible, tangible, culinary, and olfactory) experiences our bodies are subjected to (sensory input/output) in our everyday lives and in the places we inhabit. Philippopoulos-Mihalopoulos (2013: 42) gives the following example: when you walk into a room that smells of roses - which is nothing more than the smell of the rubber flooring of the room, a brand of some specific company - there might be intellectual property law at work, even if your legal experience of this specific type of law is perhaps left untouched. But you might experience, see, smell and feel the law

\footnotetext{
${ }^{5}$ Conferences like Law and the Senses (University of Westminster); Architecture, Law and the Senses (UTS, Sydney); or Synesthesia of Law (Princeton University).

${ }^{6}$ Last accessed on 03.11.2016, at http://synesthesia.princeton.edu/conference/synesthesia-of-law-what-is-it-about/.
} 
when you enter a courthouse or other authoritative institution characterized by poor health conditions, where bad smells may bespeak a hazardous work environment and disrespect for users' rights.

The law is constantly engaging the senses - through many relations with language, literature, architecture, image and sound, as well as through its tools, technologies and procedures - and it constructs its meaning by manipulating the senses in three ways: by categorizing, controlling and fooling them (Parker, 2015a; Mandic et al., 2015). Such manipulation is also a dissimulation: our consciousness is constantly directed and reshaped by socio-cultural and technological changes that the law appropriates and categorizes, inserting new properties and dismissing others.

Therefore, "the law determines an atmosphere by allowing certain sensory options to come forth while suppressing others" (Philippopoulos-Mihalopoulos, 2013: 46). It is the case with sight, which has been awarded primacy in relation to smell, touch or sound and has inspired the plain view doctrine (Khazam, 2014). But various American courts have attempted to extend the plain view doctrine to situations involving senses other than sight, like smell, thus giving rise to a "plain smell doctrine" (as in situations where an officer determines reasonable and probable grounds for search based on his/her detection of some distinctive smell, such as the odor of marijuana) and hence "putting the sense of smell on trial" (ibidem). Parker (2015a), too, claims that where the acoustic is considered, contemporary legal scholarship has been silent. But because all legal thought and practice necessarily takes place in and in relation to sound, the author argues that an acoustic jurisprudence is as relevant to the law of property as the law of torts, for the law is implicated in the making of our sonic environment and experience. The same may be said of taste: ${ }^{7}$ the notion of taste and the experience of tasting are constantly invoked in relation to the legal (Levin and Jamin, 2016; Mandic et al., 2013).

Therefore, this shift in focus, contextualizing the socio-legal in a sensorial or sense-making perception of the law, is an important statement about not only the presence of law in the quotidian moments and places of our lives, but also the role of the law in determining and affecting the way we sense, experience and acknowledge all of these (Levin and Jamin, 2016). Understanding the synesthesia of law thus proves to be "a promising tool to investigate the materiality of law's relation to the world" (Mandic et al., 2013: 7).

\footnotetext{
${ }^{7}$ In his Critique of Judgment, Kant describes the principle of taste as the "subjective principle of judgment in general", although he is particularly concerned with the legitimacy of judgments of beauty and not with legal experience. Last accessed on 17.02.2017, at https://plato.stanford. edu/entries/kant-aesthetics/.
} 


\subsection{Material Socio-Legal Studies}

Although it is often portrayed as an abstraction, the law has a materiality that pervades all aspects of our social environment, and so normativity is projected onto all components of our physical world. Thus, legal phenomena are materialized in the sense that law presents itself in the form of and with the quality of a thing (Brigham, 2009b: 16). The material forms of the law include such things as parking meters, certificates, signs, maps and also buildings, whose meanings are open to interpretation and may become caught up in a range of legal practices (Ewick and Silbey, 1998; Braverman et al., 2013). Brigham (2009b) offers the following examples: in New York city, a license to provide sidewalk dining can affect the fortunes of some restaurants in the summer, and the kiosks on the streets of the city were statutorily created in the hope that the social life to which they gave rise would reduce crime. Thus, material socio-legal studies highlight the fact that many of the things we take for granted have resulted from socio-cultural processes and legal constructions, thus establishing a law-in-context perspective.

All of these material forms and things are present in spaces and places, which means that almost all aspects of law have some "spatial frame of reference" (Braverman et al., 2013: 1). Therefore, the law has discovered "its situatedness", which in turn makes legal theory at ease with concepts like mapping or territory, and socio-legal scholarship with geographical terminology and practices (Philippopoulos-Mihalopoulos, 2010: 187). However, this new scholarship on the spatial and material dimensions of the law "forces it into dealing with a new kind of uncertainty", which may conflict with the positivistic idea of the law as "immaterial, universal and abstract" (ibidem: 189).

One specific place where law takes shape and shapes our experience of law itself is the courthouse and the courtroom. A trial is an event that establishes a certain kind of space, and in order to acquire the force of law it needs to be recognized by society as an institution. Hence the symbolic importance of the courthouse in the cultural imagination of many peoples (Dahlberg, 2016) - just consider the example of the iconic United States Supreme Court building. Courthouses are a product of the circumstances of time - the historical, political, economic, legal, social, technological and cultural contexts as well as of legal tradition and of the place of jurisdiction (Branco, 2016). Thus, the buildings that objectify, situate, symbolize, and dispense justice are understood both as law and as the expression of law, incorporating the ideologies of policy makers, architects, and legal professionals, as well as those of citizens (Brigham, 2009b). 
Consequently, places and things are moulded by law, and the law is moulded by places and things. Even our bodies are 'objects' of the material world (Palmer, 1998).

\subsection{Interactive Ecologies of Knowledges and Methodologies}

An interdisciplinary scholarship of humanities, culture and socio-legal studies of law is important because it allows us to look carefully into the local/national/regional/global complexities of the multiple relations between interlegality, power, identity, meaning, consciousness, conformity and contestation in our everyday lives. Legal phenomena hence need to be understood as cultural-political processes that are made sense of and disseminated through culturally specific performances, narratives, topoi, images, sounds, foods, material artefacts and in our bodies and senses, and so need to be understood with methods that extend beyond those developed in more traditional forms of legal and socio-legal scholarship (Olson, 2017; Coombe, 2001).

On this basis, Shaw (2013) argues that in order to address law in context we need a larger set of interpretative tools and capabilities than those we have used before. Critical postcolonial theory, for example, presents new challenges to law in respect of many substantive issues, such as those of power, hierarchy, wealth, diversity and justice, and also puts in question the hegemony of European modernity and its claim to universal knowledge (Otto, 1999). For that reason, Santos (2002) argues that in recent years social and theoretical conditions have developed for the construction of an interdisciplinary approach and a methodological pluralism that searches for the "absences" and the "emergences" in social and legal relations, many of which are not yet visible, and where the law is not only seen as regulation, but also as social emancipation, and where its unit of analysis is shifted from a substantive and statutory normative perspective to a critical analysis of normativity in its entirety and plurality of forms. That is why the author (Santos, 2007: 67) proposes an ecology of knowledges ${ }^{8}$ based on the idea of the "epistemological diversity of the world" and the identification of a "plurality of knowledges" that go beyond scientific knowledge, itself already plural, and promoting the interaction and interdependence between scientific and non-scientific

\footnotetext{
${ }^{8}$ As Araújo (2016) claims, these ecologies of knowledges, that challenge socio-legal studies in identifying the exclusions made by Eurocentric concepts, theories and methodologies, permit the possibility of learning about ecologies of laws and ecologies of justices that have been excluded and classified as inferior, primitive, local, residual or unproductive by those same Eurocentric modes of knowledge production and consumption, either in the global North or in the global South.
} 
knowledges' - what he has recently termed the 'epistemologies of the South' (Santos, 2014). This, of course, is not an easy task.

Manderson (2008) too advocates the use of multiple and interdisciplinary methodologies, devised around the pictures, sounds, and stories that are part of our social world. Thus we would learn to talk about the law using other forms of human expression, which have more to say about it, and will probably do it differently (and even better). As Sarat and Simon emphasize (2001: 6), it is important to "look beyond the narrowly juridical" to explain how the cultural artefacts found in everyday life illustrate, characterize, and challenge law and understandings of normativity, thus reading in those narratives, images and performances, a model of law that is more coherent and practical than the one traditionally depicted by legal studies. Thus, such a dialogue may lead to "unsuspected forms of complementarity", making it possible to recognize common preoccupations, complementary approaches and even contradictions (Santos, 2007: 75). To combine different approaches, different methodologies, suggests other forms of being and behaving, culturally, socially and normatively, and gives rise to the necessity of producing new imaginaries and listening to other voices and knowledges, thus contributing to a larger reach of humanistic-cultural-socio-legal investigation on power relations, power contestation and empowerment (Meneses, 2016; Marusek, 2012).

\section{Some Performative Connections between Law and Music}

In the vast enterprise called Law and the Humanities, an area of studies has been gathering attention: the comparison and analogies between Law and Music. While the antecedent for the musical metaphor in law can be easily traced back to some works by American legal realist Jerome Frank (1947, 1948), the topic has gained attention during the 1990s, mainly, but not only, in common law legal culture (Manderson 1999, 2000; Rouland, 2001; Lopes, 2006).

Law and music have most often been associated through the concept of interpretation (Frank, 1947; Ruffier-Méray, 2007; Resta, 2011; Brunello and Zagrebelsky, 2016). Authors have focused on the idea that the law is best understood as a performative art (Balkin and Levinson, 1991; Linhares, 2004). As is the case with theatre, music, dance, and other performative arts, law as a practice can be seen as an endeavor in which the moment of creation is

\footnotetext{
9 Santos argues the need to confront scientific knowledge with what he calls the 'epistemologies of the South', which concern the production and validation of knowledges based in the experiences of resistance of those social groups that have systematically suffered injustice, oppression and destruction caused by capitalism, colonialism and patriarchy (Bhambra and Santos, 2017).
} 
essentially separate from that of execution, with all the spaces and contradictions that the analysis of this hiatus can show (Nitrato Izzo, 2007).

Although until recently the issue of interpretation has been one of the most immediately accessible ways in which the relationship between law and music was read, with a problematic preference for classical music over other musical modes as the term of comparison, further developments in the field have gained attention. The sonic normativity of law is something that had already attracted the attention of French sociologist of law Jean Carbonnier - when he noted (but did not develop) his intuitions of how the different sounds and intonation of commands, threats and even conflicts of jurisdiction in the voices of judges could be of legal significance (see on this Nisio, 2002: 36-37). Parker has been able to show how law and justice have been deaf with regards to matters of music and sound as a consequence of privileging other forms of thought, expression and art, most notably literature, images, architecture or cinema. Parker's argument rests on placing law on the list of subjects that could benefit from a closer dialogue with sound rather than music, broadening legal dialogues by including sonic studies (Parker, 2015b: 29). These approaches reveal that how law reacts to, produces and regulates sound, music, or the audible is a matter of how important these features are and the role they can play in a given legal culture and as means of dispute resolution (Petersen, 1998). In Western legal culture, in both civil and common law cultures, the idea of performing the law, evoking a singularity of decisions, has been seen as a threat to the advances of modern law in terms of its predictability, stability and, in many respects, its mythology (Grossi, 2007; Fitzpatrick, 2001). In historical terms, the development of the theoretical tools of law and music followed similar paths of rationalization (Rouland, 2001). While not everything about modernity must necessarily be discarded, what is left out of this association is the perception that musical thinking can support the enhancement and expansion of our understanding of legal reason and reasoning processes as a different kind of fit between law and art (Mittica, 2013).

This is the case made by those who reflect on the possibilities of applying improvisation, as a mode of thinking, to legal knowledge - which is also a recent and fresh way of relating legal studies and music. In recent years improvisation has become a concept that has attracted a great deal of attention, beyond aesthetics and musicology. Understood as a social practice, improvisation can prove useful as a heuristic concept in non-musical contexts (Bachir-Loopuyt et al., 2010), thus expanding its application to other social practices (Sparti, 2005, 2010). Contrary to what it is often superficially understood to be, improvisation is a practice that rests on competences and skills 
that are acquired prior to the agent putting it into action. Improvisation can be seen as a kind of "logic of creativity" (Sparti, 2005) that seems to be far from the traditional concept of legal practice. This is traditionally associated with the predictability of decisions - to legal certainty, as the most important value for social behavior -, while improvisation expresses the opposite in that it opens to the unknown, exploring and searching the new. But law is not perfectly formed, and its improvisational character emerges in its often neglected, singular and unpredictable elements, by means of which the law is reconciled with justice as improvisation (Ramshaw, 2013). In historical terms, Manderson has shown how the abandoning of improvisation in music happened at the same time law was entering an age of legal formalism. The stress on rationalization, based on the predominance of the text, rapidly evolved into a 'textual anxiety', favoring abstraction, formal rigor and internal coherence (Manderson, 2010: 3-5). Understanding law as improvisation can thus help us to experience alternative views of different strategies in legal education beyond traditional text-based transmission of legal knowledge and expertise (Lycouris and Timmons, 2012).

But what, apart from an alternative reconstruction of legal reasoning, can improvisation contribute to legal studies? A changed vision of the law, enriched by elements of a culture of improvisation. Manderson answers that it offers the opportunity of a novel fusion between law and music through improvisation, in the sense of fostering, involvement and agency (2010: 7). Looking at improvisation as a practice grounded in aesthetic value and as a generative force of social meanings can be seen as a blueprint for reinforcing the importance of law as something that can be practiced, and even improvised, in everyday life. It can also illuminate rather difficult ways of thinking about the performance of the law when the path to be followed has not been fully mapped out. From this point of view, and given that the performativity of the law is almost unavoidable, a 'musical understanding' of the law may be able to deal with (supposedly) controversial legal concepts precisely because they do not fit the standard theory of legal reasoning. ${ }^{10}$ The focus on music, law and improvisation allows for a shift from the long-assumed, literature-based legal imagination (White, 1985; Ost, 2004; Nussbaum, 1990) to a more performative one. Thinking legally in terms of improvisation can make available to us a more dynamic understanding of normativity and thus enhance our legal imagination (Piper, 2010), one that is based fruitfully on legal performances as ways of challenging assigned legal and cultural

${ }^{10}$ One example could be the principle of precaution as a legal tool based on an improvisatory logic where openness to the unknown and uncertainty is introduced into legal reasoning (Gorgoni, 2010). 
meanings (Peters, 2008). From this point of view, everyday actions, such as sitting or occupying space on a bus, can lead to a timely contribution in the creation of a new meaning for equality, as was the case with the civil rights champion Rosa Parks in the 1950s when she refused to give up her seat to a white passenger. Nowadays performing spatially in a way different from that which is "normally" assigned can be normatively challenging: using space in a variety of unexpected ways - e.g. occupying more space than usual, being closer to the other users than it should be expected - produces an interaction of small normative universes that rest on a normatively grounded physical proxemics (Lassonde, 2006). The repetition of these performances as a not undesired but not totally deliberate practice, is capable of producing new normative meanings that open uncharted spaces. During the summer of 2015, in the small frontier city of Ventimiglia, on the border between Italy and France, some migrants made a surprise attempt to cross the French frontier (closed at the time, in the wake of one of the many European immigration crises). In an unexpected move, some migrants set up camp on the cliff between the two countries. This performative appropriation of space immediately rendered the frontier (as a legal concept) contested and porous, while causing the police, especially at the outset, to be surprised and partially blocked by the migrants' unsuccessful attempt to enter France. In terms of the migrants' plan to cross the border, this action did not have a positive outcome, but it does show well how improvised social performances can transform acquired legal meanings.

Resisting the law means performing it the other way around, giving space to contingency through an ethics of improvisation. Hence, law can be seen as culturally grounded in a constant "aesthetics of imperfection" based on the event of the performance (Hamilton, 2000) that attests to the presence of all the different forces, cultures and struggles and makes the legal enterprise more prone to exceed its autonomous limits. While not everything in law can be improvisation, there is much to be gained from developing a kind of improvisatory legal reasoning; specifically, the way in which the law is able to continuously iterate itself while also expressing the potential to change its very foundations, as can be shown by all actors engaged in their appropriation of the uses of the law. In concluding this section, it is possible to affirm that in music as well as in law we do not improvise because we do not know something, but because improvisation is a way of learning what we did not know before.

\section{On Law and Food: Opening the Canon of Socio-Legal Studies}

As Caplan (1996: 3) rightly points out, food is never 'just food'. It is closely connected to social relations and cultural ideas. And with rules. We eat food 
every day (or should eat food every day). And our choices of what to eat, as well as where to buy, how to prepare and how we eat our food are bound up in a web of normative practices and commands, deriving from formal (as van der Meulen points out [2013: 71], the amount of food legislation in Europe is impressive), informal (communal and social background define eating codes and rules of conduct) and religious rules (kosher, halal and other dietary rules) and rituals, an interlegality of normative levels that organize, classify and regulate our food. Thus, questions of quality, taste/flavor and good manners are determined by a variety of cultural practices, values and commands (Mohr and Hosen, 2014: 101). Sometimes we are conscious of these interactive levels of rules. Many times we don't even realize that much of what and how we eat is a veritable product of different rules and codes.

When food enters into the domain of public concerns and actions it is particularly prone to provoke legal conflicts. With regard to food, it is the case that a myriad of conflicting claims reflect in many ways our relationship to it as well as to law and politics. The recent controversy in Italy over school meals provides a good example, one that elucidates a whole world of conflicts about food, mediated or induced by culture. In question are not only the well-known and widespread issues regarding the diversity of diets to be provided according to different cultural and religious beliefs. The point is rather a larger interrogation concerning the constant negotiation between individual alimentary needs and the collective space opened by eating with others. Should I have the right to have my own type of food at a public meal? Should my daughter/son be allowed to eat with others even if s/he does not endorse their dietary regime (where other types of food are brought in)? Are these conflicts really manageable by the law, in order to create a framework of common guidance and principles? Or will a model of ideological decision necessarily overcome other views on the issue?

Thus, it is important to look at the many cultural narratives behind and beyond food, because they shape and are shaped by the normativities in which food is involved. Hence, food can be read as language, i.e., as a symbol or a marker of difference; or a metaphor for society and social rules, power, inclusion/exclusion, ${ }^{11}$ immigration, multiculturalism and even terrorism; ${ }^{12}$

\footnotetext{
${ }^{11}$ Food can be a marker of oppression, for what we eat can signal to others that we don't belong to their community. Hence, people can experience overt racism and shame when they eat culturally specific foodstuff or meals in public. Last accessed on 20.02.2017, at http://everydayfeminism. com/2016/09/food-is-a-political-issue/.

12 As discussed by Mohr and Hosen (2014: 101), the cultural dimensions involved in immigration and a "diversity of ethnic groups living, eating and shopping side-by-side" have been also used by xenophobic politicians, and even linked to problems of social cohesion and terrorism, as happened recently in the Australian context.
} 
it encompasses history, geography, class, gender and identity; changes in consumption signal the fact that food is political and is tied up with capitalism, industrialization, the rise of food technology and the merging of agricultural and chemical industries (Caplan, 1996; Mohr and Hosen, 2014; Meneses, 2016).

Furthermore, all our senses are involved when it comes to food: we see it, we feel it, we touch it, we smell it, and we taste it. It is material, it affects us, it becomes a part of us, and it is emotional. Thus, materiality and synesthesia are fundamental in this relation between food and law, as well as between law and food.

If, as Manderson (2008: 255) claims, law is a social fact, then, as the same author points out, we should "talk about it using the whole 'chocolaty' language of our social world". 'Chocolaty' is the apt word here, and although chocolate is not one of the items discussed in this section, this 'chocolaty language' of the law serves as a brilliant metaphor for the arguments that we will deal with in this section. In addition, all that is related to the action of processing food has also to do with the search and production of knowledge, where theory and practice engage in a constant dialogue (Meneses, 2013).

Recently, food and cuisine seem to have acquired greater importance in Western societies, with tv shows such as Masterchef or Hell's Kitchen featuring as primetime series, and chefs such as Jamie Oliver or Gordon Ramsay, ${ }^{13}$ with their own shows and books, being recognized as tv stars and playing pivotal roles in shaping the ways we envisage food and gastronomies. As Mohr and Hosen (2014: 112) assert, gastronomy regulates how we should eat, and ethnicity determines the cuisines of different cultures, which may be "eagerly devoured by neophiles and reviled by reactionaries". Food is also a badge of national identity. This is certainly the case when 'national foods' are at stake. Recently, Jamie Oliver dared to modify the recipe for paella (a Spanish staple rice dish) by adding chorizo, ${ }^{14}$ and this prompted immediate outrage. Perhaps what really matters is not chorizo, but what it conceals and reveals. As Palmer argues (1998: 65), "the history of any nation's diet is the history of the nation itself". It is made up of inclusion/exclusion, and so food may speak of difference and discrimination and wicked legal regimes. Thus, chorizo may trigger the memory of the dark role paella played during the Spanish Inquisition and how Moors and Jews were exposed to persecution

\footnotetext{
${ }_{13}$ As Tran and Harden point out, these chefs are white. Therefore, "What We Think of as 'Good Food' Is White Food”, which means that the standards of excellence used are Eurocentric. Last accessed on 20.02.2017, at http://everydayfeminism.com/2016/09/food-is-a-political-issue/.

${ }^{14}$ Last accessed on 25.10.2016, at http://www.telegraph.co.uk/news/2016/10/04/jamie-oliver-angers-spaniards-with-insulting-paella-recipe/.
} 
and expulsion. ${ }^{15} \mathrm{~A}$ food with a similar history is the Portuguese alheira, a sausage that is not made of pork but of poultry, and is seen as the 'sausage of resistance', as it was invented to look like chorizo. It was a practice of struggle that, during the Inquisition, allowed newly, forcibly-converted Jews not to eat pork by eating a sausage that seemed like chorizo and thus saved them from being persecuted and killed. ${ }^{16}$

The current foodie culture (with so many bloggers talking and writing about food and restaurants) and the diversity of foods in Western cultures have made food a markedly democratic facet of modern societies. ${ }^{17}$ However, the democratic nature of food in modern popular culture is countered by the reality of segregation and exclusion, as hunger and malnutrition still affect more than two billion people in the world (UN, 2010). There is a sort of paradox here: while more and more people get to be interested in food, gastronomy, restaurants, five star chefs and the rest of it, a large percentage of people still have to fight for their right to have access to adequate food, a fundamental right recognized in the 1948 Universal Declaration of Human Rights and in other international legal instruments (ibidem).

It is in the context of armed conflict that the right to food seems to have the greatest impact on people's lives (although, as UN factsheet no. 34 argues, armed conflicts and natural catastrophes account for only 10 percent of deaths by famine). The war in Syria is one such example, and Madaya Mom embodies the daily struggle for the right to food. Madaya Mom, a free digital comic created by ABC News and Marvel Comics and illustrated by Dalibor Talaji, tells the true story of an anonymous mother of five as she and her family struggle to survive in the city of Madaya. According to Giddens (2012: 85), comics - a contemporary, unique, and aesthetically rich narrative medium - should be included "amongst the resources considered in the interdisciplinary study of law". As described by The Guardian, ${ }^{18}$ Madaya Mom's first published post described the family's one daily meal of rice and beans; and the caption on the first page of the comic was: "Our bodies are no longer used to eating. My children are hungry but are getting sick, severe stomach pains from the food because their bodies aren't able to digest and absorb the food because they were hungry for so long". But food, in this context, is more than a

\footnotetext{
${ }^{15}$ Last accessed on 11.11.2016, at https://www.theguardian.com/lifeandstyle/2016/oct/07/paellas-dark-role-in-the-spanish-inquisition.

${ }^{16}$ Richard Zimler's O último cabalista de Lisboa (Lisboa: Quetzal Editores, 1996) is interesting on this issue.

${ }_{17}$ Last accessed on 08.11.2016, at https://culturedecanted.com/2014/10/19/eating-yourself-we-consume-identity-through-food/.

${ }^{18}$ Last accessed on 31.10.2016, at https://www.theguardian.com/world/2016/oct/04/madaya-mom-marvel-abc-news-syrian-war.
} 
material necessity. Thus, Madaya Mom is quite revealing, not only because it was created and published by a large mainstream publisher, Marvel, but also because Madaya Mom is not a common hero, not the typical, flying crime fighter that we are used to, such as Superman with his extraordinary powers. The character is based on a real person, a real woman/mother, without any super powers, but who is confronted with a real battle, that of survival, and whose actions support her claim to have access to food - which is, in reality, a simple claim of access to her basic rights: first and foremost, the right to life (hers and her family's). As Meneses (2013) argues, the image of the hungry body also symbolizes the struggle against the attempts of domination, and through food, or the lack of it, the character gives her voice to all those who have been kept silent and silenced by the warlords and world political powers. Furthermore, food provides visibility to several contemporary challenges that must be met by the law, such as ecological, technological, geopolitical, military and social problems.

Another comic character worth mentioning is Mafalda, created by the Argentinian cartoonist Quino. Mafalda's aversion to soup is well-known, and soup features in a number of the comic strips devoted to the six-year-old girl and published between 1964 and 1973. Her aversion to soup is not just the typical dislike a child would show for any food that adults usually impose as a healthy one. Soup is a metaphor that stands for any type of authoritarian regime that people are forced to 'stomach'.$^{19}$ It reveals intergenerational conflicts and familial relationships. Soup is, in the end, about children's rights, and Mafalda's criticism, as in the case of Madaya Mom, is a way of giving a voice to children living under authoritarian regimes.

Particular foods and meals are also intertwined with family relationships and, thus, with family law. The Sunday meal, for example, stands as a powerful metaphor for the 'family', and its decline may signal changes in the nature of family life (Caplan, 1996), possible intergenerational conflicts, the individualization of family ties and new types of families. Other examples are the offer of arroz doce (sweet rice), in the region of Coimbra, in Portugal, still used by the bride-to-be to communicate she will wed soon, and the wedding cake, which, as explained by Charsley (1996), marks the rite of passage from single to married life. Both foods are not only part of local and popular cultures, they also signal changes in legal status, embodying rights and duties/obligations.

An interesting example that underscores a possible conflict between dietary choices and the best interest of the child - a well-known legal principle in

${ }_{19}$ Last accessed on 08.11.2016, at http://www.letras.ufscar.br/linguasagem/edicao08/artigosdeic_maceres.php. 
family law - is the movie Hungry Hearts, ${ }^{20}$ directed by Saverio Costanzo (2014), where the mother, in her quest to save her child from a polluted and contaminated world, feeds the baby only with seeds and the vegetables she grows herself, putting the child's health at risk. In real life, there have been many examples where the courts have had to deal with similar situations (as in the US and in France, ${ }^{21}$ for example). And an Italian MP, Elvira Savino, has proposed a law (Atto Camera 3972, July 2016) to penalize parents who impose a vegan diet on their children (under the age of 16). Although courts, politicians and administrative institutions (such as school boards) claim they are concerned with the best interest of the child in terms of his/her healthy development, their conducts may reveal a prejudice against alternative ways of food consumption (veganism) and the imposition of what is perceived as a legitimate dietary regime - in this case, an omnivorous diet (it should be noted that the American Dietetic Association [2009: 1266], ${ }^{22}$ for example, maintains that well-planned vegetarian and vegan diets are appropriate throughout the human life cycle).

Food can also be seen as an equivalent of a legal remedy, as it was in the case of Bettie Joe, ${ }^{23}$ whose story was told in an episode of My 600lb Life. As Bettie Joe explained, although she was a 'chunky child', her addiction to food started to spiral out of control when she was sexually assaulted in her teens. Thus, an obesity problem - and the tv show My $600 \mathrm{lb}$ Life is, after all, a reality show about obese people on the verge of death and their fight for a better life - is not just about food habits and questions of health, but in fact masks normative issues that perhaps were not dealt with through recourse to the law and the legal system, at the institutional level. It is about food as comfort, a sort of legal remedy, as if food could provide the security and safety that the legal system could not. As Bettie explains, "I thought that if I was bigger I could protect myself". ${ }^{24}$ Obesity is also interrelated with discrimination issues, even at the level of the working place, and it may reveal social inequalities and hurdles in accessing the law.

Hence, food is something more than 'fuel', or a mere object of study. It is an important part of our social, cultural and legal identities.

\footnotetext{
${ }^{20}$ Last accessed on 08.11.2016, at http://www.imdb.com/title/tt3344922/.

${ }^{21}$ Last accessed on 11.11.2016, at https://www.theguardian.com/world/2011/mar/29/ vegans-trial-death-baby-breast-milk.

${ }_{22}$ Last accessed on 11.11.2016, at http://www.vrg.org/nutrition/2009_ADA_position_paper.pdf.

${ }^{23}$ Last accessed on 08.11.2016, at http://www.tlc.com/tv-shows/my-600-lb-life/photos/ where-are-they-now-bettie-jo-and-susan/.

${ }^{24}$ Last accessed on 08.11.2016, at http://www.dailymail.co.uk/femail/article-3550269/Obese-pregnant-woman-lost-200lbs-forced-decide-live-potentially-paralyzing-mass-spine-risk-baby-s-life-surgery.html.
} 


\section{Concluding Remarks}

The relationship between law, culture and the humanities will probably remain problematic for years to come (Balkin and Levinson, 2006; Douzinas, 2009). However, the development in scholarship in this particular field over the last decades already offers a body of work on which to ground a reflection about its meaning in and outside legal discourse and academia.

In this paper we have identified what we consider to be the four most interesting recent thematic issues in this scholarship. Furthermore, we analyzed some of the connections between law and music, and law and food. Seeing, smelling, hearing, touching or tasting the law in the nature of material things and the material in the nature of law is, of course, an obvious challenge (Brigham, 2009b), that requires a complex interaction of theories, practices and methodologies, and convokes all the senses. This work calls attention to this constitutive process. Interdisciplinarity is, thus, important for socio-legal studies and legal theory, because it helps to locate law in context, providing for a better perception of the juridical reality (Feenan, 2009).

Courses such as law and literature and law and film are now offered by a number of institutions and in various curricula of studies worldwide. However, even these considerable increases in the range of opportunities to study the relationship between law and the humanities do not fully reflect the field's possible plurality. By this we mean that a substantial part of the scholarship is not reflecting interest in, for example, non-European, non-English-Language cultural materials of legal and social interest. While this can be seen as just another demonstration of the dominant forces in global academia, further efforts should be made toward reinforcing scholarship from neglected cultural contexts. At the same time, new and alternative venues, where encounters between mainstream and emergent scholarship can take place, need to be established urgently. It is important to recognize the massive and interconnected changes taking place in the world, with massive and interconnected effects and consequences in social, political and normative terms, which cannot be understood through the traditional resources provided by legal and socio-legal scholarship alone.

In other respects, law, culture and humanities approaches need to further advance their claims to a role in global and national socio-legal education. In order to escape the dangers of being placed in a corner with all the other "cultural but not professional" courses that still survive in socio-legal studies programs as well as in law schools, a more vibrant contribution is needed. It could establish fruitful collaborations with other methodologies, with which a dialogue could be reciprocally beneficial. One way of doing this would be 
to establish a kind of "clinical legal education and the humanities" 25 where challenging approaches to law, culture and the humanities are inserted in the practice and in the performance of law in clinical legal programs. For example, the improvisational understanding of law could help to explore alternative views of different strategies in legal education beyond traditional, text-based transmission of legal knowledge and expertise. The same can be said about the relations between law and food, which not only reveal the struggles for rights, but also have to do with knowledge production. Such a process would be suitable to expose students, learners and practitioners of all kinds to the difference an understanding of the links between law, culture and the humanities makes. The effort to make the nexus between law and the humanities operative also at the teaching level should not be understood as an opportunity to "monetize" in a utilitarian view the professional skills to be acquired through the use of the humanities. Rather it is the openness and plurality of cultural sources of normativity that, from the outset, should engage the student, the professional or even the lay-person approaching the law for the first time. While the situation of legal education worldwide is obviously enormously diverse, looking at the European landscape - with which the authors are more familiar - we strongly advocate for a more radical insertion of new methodologies beyond the mere addition of a "Law and..." course every so often in the law curriculum, as is the current state of things.

While this may not sound entirely new, in our eyes it is a way to avoid the dead-end paths of either a sophisticated but elitist use of the humanities in order to enrich one's cultural background without critically challenging it, or radical critical stances that are not going to have a social impact as long as they are confined to the theoretical comfort of radical academia. From this point of view, we advocate for a new phase of engagement between law, culture and the humanities in which socio-legal studies as well as other disciplines (legal theory, anthropology of law, criminology, etc.) would build on the scholarship of the past in order to follow new paths in and outside academia and law schools.

The details on how to do so are yet to be created and defined. With this piece we hope to foster and engage in a discussion on how to advance our understanding of the constantly changing contours of law, culture and the humanities.

\section{Edited by João Paulo Moreira}

${ }^{25}$ While in this text the authors focused on cultural and performative understandings of the law in relation to the humanities, a theoretical antecedent of the link between clinical legal education and humanities can be found in the philosophy of Gian Battista Vico (Heritier, 2017). 


\section{References}

Araújo, Sara (2016), "O primado do direito e as exclusões abissais: reconstruir velhos conceitos, desafiar o cânone”, Sociologias, 43, 88-115.

Bachir-Loopuyt, Talia; Canonne, Clément; Saint-Germier, Pierre; Turquier, Barbara (2010), "Improvisation: usages et transferts d'une catégorie", Tracés - Revue de Sciences Humaines, 18, 5-20.

Balkin, Jack M.; Levinson, Sanford (1991), "Law, Music and Other Performing Arts", University of Pennsylvania Law Review, 139, 1597-1655.

Balkin, Jack M.; Levinson, Sanford (2006), "Law and the Humanities: An Uneasy Relationship", Yale Journal of Law \& the Humanities, 18, 155-187.

Bhambra, Gurminder K; Santos, Boaventura de Sousa (2017), "Introduction: Global Challenges for Sociology", Sociology, 51(1), 3-10.

Branco, Patrícia (2016), "Courthouses as Spaces of Recognition, Functionality and Access to Law and Justice: A Portuguese Reflection”, Oñati Socio-Legal Series, 6(3), 426-441.

Branco, Patrícia; Mohr, Richard (2015), "Odore di Napoli: What if Jurisprudence Came to us through Smell?", Non Liquet: The Westminster Online Working Papers, Law and the Senses Series, 58-75.

Braverman, Irus; Blomley, Nicholas; Delaney, David; Kedar, Alexandre (2013), "The Expanding Spaces of Law: A Timely Legal Geography", Buffalo Legal Studies Research Paper Series, Paper No. 2013-032.

Brigham, John (2009a), "Seeing Jurisdiction: Some Jurisprudential Issues Arising from Law Being '... All Over', Law and Policy, 31(1), 381-404.

Brigham, John (2009b), Material Law. A Jurisprudence of What's Real. Philadelphia: Temple University Press.

Brunello, Mario; Zagrebelsky, Gustavo (2016), Interpretare. Dialogo tra un musicista e un giurista. Bologna: il Mulino.

Caplan, Pat (1996), "Approaches to the Study of Food, Health and Identity", in Pat Caplan (ed.), Food, Health and Identity. Abingdon / New York: Routledge, 1-30.

Carlson, Kerstin (2013), "Found in Translation: The Value of Teaching Law as Culture", Drexel Law Review, 5, 407-420.

Charsley, Simon (1996), "Marriages, Weddings and their Cakes", in Pat Caplan (ed.), Food, Health and Identity. Abingdon / New York: Routledge, 50-69.

Coombe, Rosemary (2001), "Is There a Cultural Studies of Law?", in Toby Miller (ed.), A Companion to Cultural Studies. Oxford: Blackwell Publishers, 36-62.

Cotterrell, Roger (2004), "Law in Culture", Ratio Juris, 17(1), 1-14.

Cotterrell, Roger (2008), "Law and Culture - Inside and Beyond the Nation State", Retfoerd: Nordisk JuridiskTidsskrift, 31(4), 23-36.

Dahlberg, Leif (2016), Spacing Law and Politics: The Constitution and Representation of the Juridical. Abingdon / New York: Routledge. 
Darian-Smith, Eve (2013), "Postcolonial Theories of Law", in Reza Banakar; Max Travers (eds.), Law and Social Theory. Oxford: Hart Publishing, 247-264 [2 $2^{\text {nd }}$ edition].

Douzinas, Costas (2009), "A Humanities of Resistance: Fragments for a Legal History of Humanity”, in Austin Sarat; Matthew Anderson; Cathrine O. Frank (eds.), Law and the Humanities: An Introduction. Cambridge: Cambridge University Press, 49-72.

Ewick, Patricia; Silbey, Susan (1998), The Common Place of Law. Stories from Everyday Life. Chicago: The University of Chicago Press.

Feenan, Dermot (2009), "Foreword: Socio-legal Studies and the Humanities”, International Journal of Law in Context, 5, 235-242.

Fitzpatrick, Peter (2001), Modernism and the Grounds of Law. Cambridge: Cambridge University Press.

Frank, Jerome (1947), "Words and Music: Some Remarks on Statutory Interpretation", Columbia Law Review, 47(8), 1259-1278.

Frank, Jerome (1948), "Say it with Music”, Harvard Law Review, 6, 921-957.

Giddens, Thomas (2012), "Comics, Law, and Aesthetics: Towards the Use of Graphic Fiction in Legal Studies”, Law and Humanities, 6(1), 85-109.

Gorgoni, Guido (2010), “'(Pre)caution Improvisation Area': Improvisation and Responsibility in the Practice of the Precautionary Principle”, Lex Non Scripta, Ars Non Scripta: Law, Justice, and Improvisation, Critical Studies in Improvisation / Études critiques en improvisation, 6(1), 1-6.

Grant, Morag J. (forthcoming), “Musical Communication, 'Hate Speech', and Human Rights Law”, in Werner Gephart; Jure Leko (eds.), Law and the Arts. Frankfurt am Main: Klostermann.

Grossi, Paolo (2007), Mitologie giuridiche della modernità. Milano: Giuffrè.

Hamilton, Andrew (2000), "The Art of Improvisation and the Aesthetics of Imperfection", British Journal of Aesthetics, 40(1), 168-185.

Heritier, Paolo (2017), "Vico e le Law and Humanities nella clinica legale della disabilità e della vulnerabilità”, in Flora Di Donato; Francesca Scamardella (eds.), Il metodo clinico-legale. Radici teoriche e dimensioni pratiche. Napoli: Editoriale Scientifica (in press).

Khazam, Olivia (2014), "It's Right Under your Nose! The Trial of the Senses and the 'Plain Smell' Doctrine”. Accessed on 11.11.2016, at http://www.centreforsensorystudies.org/occasional-papers/its-right-under-your-nose-the-trial-of-the-senses-and-the-plain-smell-doctrine/.

Knox, Sara L.; Davies, Cristyn (2013), "The Force of Meaning. Cultural Studies of Law”, Cultural Studies, 27(1), 1-10.

Lassonde, Julie (2006), Performing Law. Victoria: Faculty of Law, University of Victoria. Accessed on 20.11.2016, at http://www.law.uvic.ca/lassonde/HTML/ PERFORMING\%20LAW\%20-\%203.html. 
Levin, Thomas; Jamin, Christophe (2016), "Synesthesia of Law. An International \& Multi-Disciplinary Conference”. Accessed on 11.11.2016, at http://www.princeton. edu/international/partnerships/council/research-partnership/sciences-po/Levin-Jamin.pdf.

Linhares, José Manuel Aroso (2004), "O logos da juridicidade sob o fogo cruzado do ethos e do pathos: da convergência com a literatura (law as literature, literature as law) à analogia com uma poiêsis-technê de realização (law as musical and dramatic performance)", Boletim da Faculdade de Direito da Universidade de Coimbra, 80, 59-135.

Lopes, Mônica Sette (2006), Uma metáfora: música e direito. São Paulo: Ltr.

Lopes, Mônica Sette (2010), “A ironia e a imagem do direito: a expressão da justiça na caricatura e na charge”, in Bruno Amaro Lacerda; Mônica Sette Lopes (eds.), Imagens da Justiça. São Paulo: Editora LTDA.

Lycouris, Sophia; Timmons, Wendy (2012), "Physical Literacy in Legal Education: Understanding Physical Bodily Experiences in the Dance Environment to Inform Thinking Processes within Legal Education”, in Zenon Bankowski; Maksymilian Del Mar; Paul del Maharg (eds.), The Arts and the Legal Academy: Beyond Text in Legal Education. Farnham: Ashgate, 51-65.

Manderson, Desmond (1999), "Et Lex Perpetua: Dying Declarations \& Mozart's Requiem", Cardozo Law Review, 20, 1621-1648.

Manderson, Desmond (2000), Songs without Music: Aesthetic Dimensions of Law and Justice. Berkeley / Los Angeles / London: University of California Press.

Manderson, Desmond (2008), "Desert Island Discs (Ten Reveries on Pedagogy in Law and the Humanities)", Law and Humanities, 2(2), 255-270.

Manderson, Desmond (2010), "Fission and Fusion: From Improvisation to Formalism in Law and Music", Lex Non Scripta, Ars Non Scripta: Law, Justice, and Improvisation, Critical Studies in Improvisation / Études critiques en improvisation, 6(1), 1-9.

Mandic, Danilo; Nirta, Caterina; Pavoni, Andrea; Philippopoulos-Mihalopoulos, Andreas (2015), "Introduction: Law and Smell", Non Liquet: The Westminster Online Working Papers, Law and the Senses Series: The Smell Issue, 3-9.

Mandic, Danilo; Nirta, Caterina; Pavoni, Andrea; Philippopoulos-Mihalopoulos, Andreas (2013), "Introduction: Law and Taste", Non Liquet: The Westminster Online Working Papers, Law and the Senses Series: The Taste Issue, 3-10.

Marusek, Sarah (2007), "Between Disability and Terror: Handicapped Parking Space and Homeland Security at Fenway Park", International Journal for the Semiotics of Law, 20, 251-261.

Marusek, Sarah (2012), Politics of Parking: Rights, Identity, and Property. Abingdon / New York: Routledge.

Marusek, Sarah (2016), "Exploring Layers of Law and the Sensory at the Volcano", in Sarah Marusek (ed.), Synesthetic Legalities: Sensory Dimensions of Law and Jurisprudence. Abingdon / New York: Routledge, 1-9. 
Meneses, Maria Paula (2013), "Para ampliar as epistemologias do Sul: verbalizando sabores e revelando lutas”, Configurações, 12, 13-27.

Meneses, Maria Paula (2016), "Amplifying the Epistemologies of the South through Flavors: Dialogues from Women's Knowledges in Mozambique”, Revista Andaluza de Antropología, 10, 10-28.

Merry, Sally Engle (1998), "Law, Culture, and Cultural Appropriation”, Yale Journal of Law \& the Humanities, 10(2), 575-603.

Mezey, Naomi (2015), "Mapping a Cultural Studies of Law", in Austin Sarat; Patricia Ewick (eds.), Handbook of Law and Society. Chichester: Wiley-Blackwell, 39-55.

Mittica, Maria Paola (2013), “The Deception of Cadence: Towards a Dissonant Law", Law and Humanities, 7(2), 151-169.

Mohr, Richard; Hosen, Nadirsyah (2014), "Crossing Over: Hosts, Guests and Tastes on a Sydney Street”, Law Text Culture, 17(1), 100-128.

Moran, Lesley J. (2012), "Visual Justice: A Review Essay”, International Journal of Law in Context, 8, 431-436.

Nisio, Francesco Saverio (2002), Jean Carbonnier. Giappichelli: Torino.

Nitrato Izzo, Valerio (2007), "Interprétation, musique et droit: performance musicale et exécution de normes juridiques”, Revue Interdisciplinaire d'Études Juridiques, 58, 99-127.

Nussbaum, Martha (1990), Poetic Justice: The Literary Imagination and Public Life. Boston: Beacon Press.

Olson, Greta (2017), "Introduction: Mapping the Pluralist Character of Cultural Approaches to Law", German Law Journal, Special Issue on "Law's Pluralities: Arguments for Cultural Approaches to Law", 18(2), 233-254.

Olson, Greta (2016), "The Turn to Passion: Has Law and Literature become Law and Affect?”, Law \& Literature, 28(3), 335-353.

Ost, François (2004), Raconter la loi. Aux sources de l'imaginaire juridique. Paris: Odile Jacob.

Otto, Dianne (1999), "Postcolonialism and Law?", Third World Legal Studies, 15, vii-xviii.

Palmer, Catherine (1998), "From Theory to Practice. Experiencing the Nation in Everyday Life”, Journal of Material Culture, 3(2), 175-199.

Parker, James (2015a), "Towards an Acoustic Jurisprudence: Law and the Long Range Acoustic Device", Law, Culture and the Humanities, 1-17.

Parker, James (2015b), Acoustic Justice. Listening to the Trial of Simon Bikindi, Oxford: Oxford University Press.

Peters, Julie Stone (2008), "Legal Performance Good and Bad", Law Culture and Humanities, 4(2), 179-200.

Petersen, Hanne (1998), "On Law and Music from Song Duels to Rhythmic Legal Orders?”, Journal of Legal Pluralism, 41, 75-87.

Philippopoulos-Mihalopoulos, Andreas (2010), “Law's Spatial Turn: Geography, Justice and a Certain Fear of Space”, Law, Culture and the Humanities, 7(2), 187-202. 
Philippopoulos-Mihalopoulos, Andreas (2013), “Atmospheres of Law: Senses, Affects, Lawscapes”, Emotion, Space and Society, 7, 35-44.

Piper, Tina (2010), "The Improvisational Flavour of Law, the Legal Taste of Improvisation", Lex Non Scripta, Ars Non Scripta: Law, Justice, and Improvisation, Critical Studies in Improvisation/Études critiques en improvisation, 6(1), 1-5.

Ramshaw, Sara (2013), Justice as Improvisation. The Law of the Extempore. Abingdon: Routledge.

Resta, Giorgio (2011), "Il giudice e il direttore d'orchestra. Variazioni sul tema: 'diritto e musica", Materiali per una storia della cultura giuridica, 41(2), 435-460.

Rouland, Norbert (2001), "La raison, entre musique et droit: consonances", Actes $d u$ colloque Droit et musique. Aix-en-Provence: Les Presses universitaires d'Aix-Marseille, 109-191.

Ruffier-Méray, Jahiel (2007), "Lire la partition juridique. Interprétation en droit et musique”, in Jean-Jacques Sueur (ed.), Interpréter et traduire. Bruxelles: Bruylant, 233-272.

Santos, Boaventura de Sousa (1995), Toward a New Common Sense: Law, Science and Politics in the New Paradigmatic Transition. New York / London: Routledge.

Santos, Boaventura de Sousa (2002), Toward a New Legal Common Sense. Law, Globalization, and Emancipation. London: Butterworths.

Santos, Boaventura de Sousa (2007), "Beyond Abyssal Thinking. From Global Lines to Ecologies of Knowledges”, Review (Fernand Braudel Center), 30(1), 45-89.

Santos, Boaventura de Sousa (2014), Epistemologies of the South. Boulder: Paradigm.

Sarat, Austin; Anderson, Matthew; Frank, Cathrine O. (2010), "Introduction. On the Origins and Prospects of the Humanistic Study of Law", in Sarat Austin; Matthew Anderson; Cathrine O. Frank (eds.), Law and the Humanities. An Introduction. New York: Cambridge University Press, 1-46.

Sarat, Austin; Simon, Jonathan (2001), "Beyond Legal Realism?: Cultural Analysis, Cultural Studies, and the Situation of Legal Scholarship", Yale Journal of Law \& the Humanities, 13(1), 3-32.

Shaw, Julia (2013), "Reimagining Humanities: Socio-legal Studies in an Age of Disenchantment”, in Dermot Feenan (ed.), Exploring the Socio of Socio-legal Studies. Basingstoke: Palgrave Macmillan, 111-133.

Silbey, Jessica (2012), "Persuasive Visions: Film and Memory", Law, Culture and the Humanities, 1(4), 6-9.

Sparti, Davide (2005), Suoni inauditi. L'improvvisazione nel jazz e nella vita quotidiana. Bologna: il Mulino.

Sparti, Davide (2010), L'identità incompiuta. Paradossi dell'improvvisazione musicale. Bologna: il Mulino.

UN - United Nations (2010), The Right to Adequate Food. Fact Sheet no. 34. Geneva: UN. van der Meulen, Bernd (2013), "The Structure of European Food Law”, Laws, 2, 69-98. 
Watt, Gary (2013), Dress, Law and Naked Truth: A Cultural Study of Fashion and Form. London: Bloomsbury Academic.

White, James Boyd (1985), The Legal Imagination. Chicago: University of Chicago Press.

Received on 24.11.2016

Accepted for publication on 07.02.2017

\section{Patrícia Branco}

Centro de Estudos Sociais, Universidade de Coimbra

Colégio de São Jerónimo, Largo D. Dinis, Apartado 3087, 3000-995 Coimbra, Portugal

Contact: patriciab@ces.uc.pt

\section{Valerio Nitrato Izzo}

Dipartimento di Giurisprudenza, Università degli Studi di Napoli Federico II

Edificio Pecoraro-Albani - Via Porta di Massa 32, 8. ${ }^{\circ}, 80138$ Napoli, Italy

Contact: valerio.nitratoizzo@unina.it

\section{Interseções entre o direito, a cultura e as humanidades}

É cada vez mais frequente o esforço desenvolvido por investigado-res e estudiosos no sentido de situar o direito nos respetivos contextos social, político, histórico e cultural. Verifica-se, simultaneamente, a necessidade de conferir ao direito e às ciências sociais novos papéis e recursos. Assim, propomo-nos ir em busca das muitas interseções entre o direito, a cultura e as humanidades, apresentando para tanto quatro grandes linhas de indagação: (1) a interlegalidade no quotidiano; (2) a sinestesia do direito; (3) os estudos sociojurídicos de natureza material; e (4) as ecologias interativas de saberes e meto-dologias. É essa a primeira parte do artigo. A segunda e a terceira partes debruçam-se sobre duas relações interdisciplinares concretas e bastante recentes: entre direito e música, e entre direito e comida. Nessa conformidade, avançamos a ideia

\section{Intersections entre loi, culture et les sciences humaines}

L'effort fourni par les chercheurs et les érudits dans le but de situer le droit dans leurs respectifs contextes social, politique, historique et culturel est de plus en plus notoire. Simultanément, il est donné de constater un besoin de conférer au droit et aux sciences sociales de nouveaux rôles et ressources. Dès lors, nous nous proposons de partir en quête des nombreuses intersections existant entre le droit, la culture et les sciences humaines, en présentant, pour ce faire, quatre grandes lignes de recherche: (1) l'interlégalité au quotidien; (2) la synesthésie du droit; (3) les études sociojuridiques de nature matérielle et (4) les écologies interactives de savoirs et de méthodologies. Il s'agit là de la première partie de l'article. La seconde et la troisième se penchent sur deux relations interdisciplinaires concrètes et assez récentes: entre droit et 
de que será oportuno expor os alunos, formandos e os profissionais da área em geral à vantagem decorrente de uma compreensão das ligações existentes entre o direito, a cultura e as humanidades.

Palavras-chave: alimentos; cultura; direito; ecologia do conhecimento; estudos sociolegais; humanidades; música. musique et entre droit et alimentation. C'est en vertu de ce qui précède que nous avançons l'idée qu'il serait opportun d'exposer les étudiants, les apprenants et les professionnels de ce domaine en général à l'avantage qui découle d'une bonne compréhension des liens existant entre le droit, la culture et les sciences humaines.

Mots-clés: aliments; culture; droit; écologie du savoir; études sociojuridiques; musique; sciences humaines. 